\title{
International Technical Seminar of the Central Tracing Agency
}

The Central Tracing Agency International Technical Seminar, organized by the ICRC, was held in Geneva from 4 to 10 November 1982. At the inaugural meeting the President of the ICRC, Mr. Alexandre Hay, welcomed the 61 participants from 53 National Red Cross and Red Crescent Societies.

The seminar - the first of its kind to be organized on such a large scale - enabled representatives of the National Societies, the League of Red Cross Societies and the ICRC to exchange their views and their experience in activities which are the specialized domain of the Central Tracing Agency in its interventions during and after conflicts, such as transmitting family news, tracing missing or separated persons and reuniting dispersed families. The establishment of national information bureaux, as provided for in the Geneva Conventions, and the development of tracing services at the National Red Cross and Red Crescent Societies were also discussed.

The delegates attending the seminar all stressed the need to create or develop National Society tracing services and requested the ICRC and the League, in conformity with the document presented by the ICRC and the League at the Twenty-fourth International Red Cross Conference in Manila in November 1981, to give the National Societies the necessary technical assistance for the training of specialized personnel. They also emphasized the advisability of organizing regional seminars and placing experts at the disposal of the National Societies, whilst calling on the latter's experience where necessary, in co-operation with the League.

Mention must be made of the excellent spirit in which the discussions, which were strictly confined to the technicalities of tracing activities, took place. The representatives of the various National Societies appreciated the importance of exchanging ideas, getting to know each other and talking over mutual problems. 
This seminar was only a first step towards collaboration between the ICRC and the National Societies in tracing activities. It is expected to be followed by other international seminars of the same kind.

In response to the delegates' requests, a technical manual based upon the results of this seminar will be compiled shortly for the National Societies.

All National Societies will be sent a detailed account of the seminar's work.

\section{First Egyptian seminar on humanitarian law}

The first Egyptian seminar on international humanitarian law, organized by the Egyptian Society of International Law, the Egyptian Ministry of Defence and the ICRC, was held in Cairo from 20 to 24 November. The ICRC delegation at this seminar was headed by Mr. H. Huber, Vice-President of the ICRC, and included several representatives of the Principles and Law Department and the Information Department.

About thirty high-ranking Egyptian officers took part in this seminar which was mainly for members of the armed forces. Also attending the seminar were high-ranking Egyptian officials and professors, as well as two Sudanese military officers.

The opening session was honoured by the presence of H. E. Mr. Boutros Boutros Ghali, Minister of State for Foreign Affairs, who made a speech in which he pointed out that Egypt had always shown a keen interest in the development of international humanitarian law, in the reaffirmation of its principles applicable in armed conflicts, in its dissemination and in the guarantee of its application. Addresses were also given by Dr. Zaki Hashem, President of the Egyptian Society of International Law, by Mr. H. Huber, Vice-President of the ICRC, by General Fouad Abdel Salam Amin, Director of Military Justice, and by Mr. Yehia Darwish, Secretary General of the Egyptian Red Crescent.

During the seminar lectures were given by professors of the Universities of Cairo and Alexandria, officers of Military Justice, senior government officials and ICRC representatives. The lectures dealt with subjects as varied as the law of war and the armed forces, humanitarian law 